Faculdade de Ciências Econômicas UFRGS

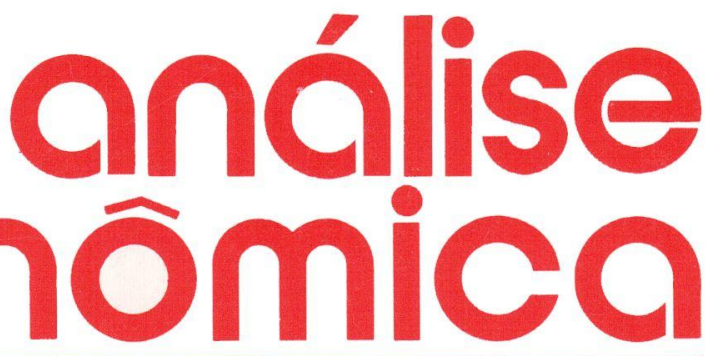

- MONETARY OVERHANG AND REFORMS IN THE 1940

Radḱger Dornbusch

Holger Wolf

- ALTA INFLAČ̃o E ESTABLLIZAÇÃo: GRADUALISMO OU TRATAMENTO DE CHOQUE

Fernando J. Cardim de Carvalho

- A ABORDA GEM MICROECONOMICA DA INDEXACAO SALARIAL

Gícomo Belbinotto Nete

- "OS NEO-RICARDIANOS" DE FRANK HAHN

Roberto Camps Mormes

- OS NEO-RICARDIANOS

Frank Hahn

- INCDENCIA TRIBUTÁRIA E OS GASTOS EM ALIMENTOS

Joso Rogerio Samson

- CONSID praÇÓES SOBRE A REFORMA TRIBUTARIA

Raymundo Guimarîtes

- eFErTgs espaciais da aUtomaÇáo BANCARIA

Moema Castro Debiagl

Otilin Beatris Kroefi Carrion

- DESENYOLVIMINTO ECONOMICO E A QUESTAO AME IENTAL

Ademar Ribelro Romeliro

- CONSIDERACóES SOBRE A DISGERTAÇAO DE MESTI ADO Nali de Jesus de Sorra
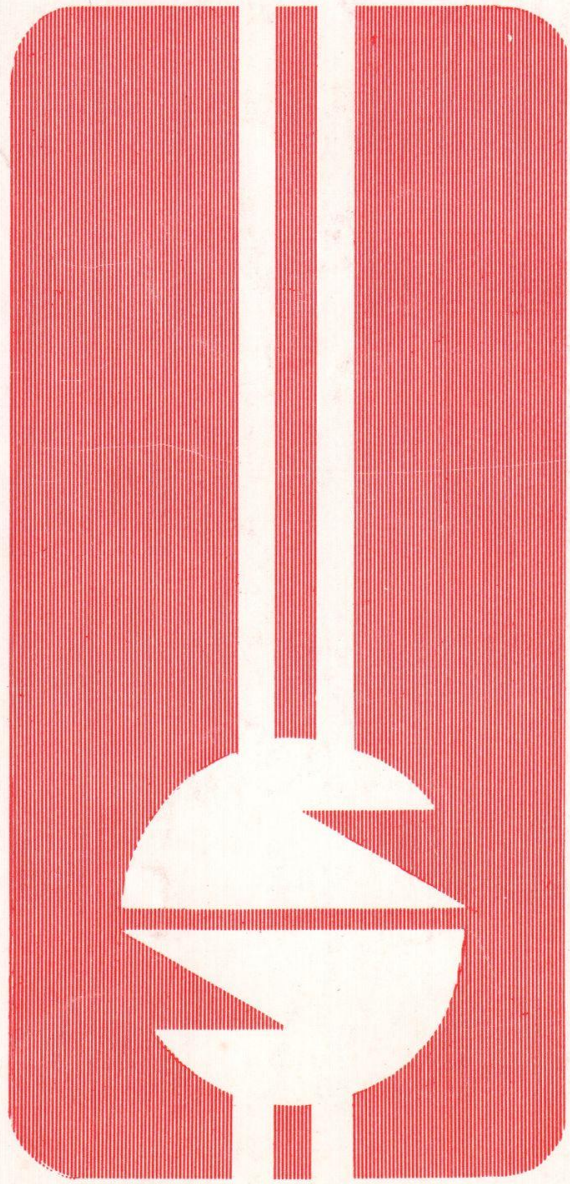
UNIVERSIDADE FEDERAL DO RIO GRANDE DO SUL

Reitor: Prof Tuiskon Dick

FACULDADE DE CIÊNCIAS ECONÔMICAS

Diretora: Prof ${ }^{a}$ Yeda Rorato Crusius

CENTRO DE ESTUDOS E PESQUISAS ECONÔMICAS

Diretor: Reinaldo Ignacio Adams

DEPARTAMENTO DE CIÉNCIAS ECONÔMICAS

Chefe: Prof. Pedro Cezar Dutra Fonseca

CURSO DE PÓS-GRADUAÇÃO EM ECONÔMIA

Coordenador. Prof. Nali de Jesus de Souza

CURSO DE PÓS-GRADUAÇÃO EM ECONOMIA RURAL

Coordenador: Prof. Atos Freitas Grawunder

CONSELHO EDITORIAL: Achyles Barcelos da Costa, Aray Miguel Feldens, Atos Freitas Grawunder, Carlos Augusto Crusius, Ernani Hickmann, João Rogério Sanson, Juvir Luiz Mattuella, Maria Imilda da Costa e Silva, Nali de Jesus de Souza, Nuno Renan Lopes de Figueiredo Pinto, Otilia Beatriz Kroeff Camion, Otto Guilherme Konzen, Paulo Alexandre Spohr, Pedro Cezar Dutra Fonseca, Reinaldo Ignacıo Adams, Roberto Camps Moraes, Valter José Stülp, Yeda Rorato Crusius, David Garlow (Wharton Econometrics Forecasts Association, E.U.A.), Edgar Auguisto Lanzer (UFSC), Eleutério F. S. Prado (USP), Fernando Holanda Barbosa (FGV/RJ), Gustavo Franco (PUC/RJ), Joaquim Pinto de Andrade (UNB), Juan H. Moldau (USP), Werner Baer (Univ. de lllinois, E.U.A.)

COMISSĀO EDITORIAL: Atos Freitas Grawunder, Pedro Cezar Dutra Fonseca, Reinaldo Ignacio Adams e Roberto Camps Moraes.

EDITOR: Nali de Jesus de Souza

SECRETARIA: Maria Ivone de Mello (normalização), Vanete Ricacheski (revisão de textos), Zélide Bregalda (Secretária)

FUNDADOR: Prof. Antôniı Carlos Santos Rosa

Os materiais publicados na revista Análise Econômica são de exclusiva responsabilidade dos autores. É permitida a reprodução total ou parcial dos trabalhos, desde que seja citada a fonte.

Aceita-se permuta com revista congêneres. Aceitam-se, também, livros para divulgaçäo, elaboração de resenhas ou recensōes.

Toda correspondência, material para publicação (vide normas na $3^{\text {a }}$ capa), assinaturas e permutas devem ser dirigidos ao seguinte destinatário:

\section{PROF. NALI DE JESUS DE SOUZA \\ Revista Análise Econômica \\ Av. João Pessoa, 52 \\ 90.040 - PORTO ALEGRE (RS), BRASIL}

Telefones: (0512) 28.1633; 24.6022 - Ramais 3440 e 3507

FAX: (0512) 25.1067 


\title{
MONETARY OVERHANG AND REFORMS IN THE 1940'
}

\author{
Rudiger Dornbusch \\ Holger Wolf \\ Massachusetts Institute of Technology
}

\begin{abstract}
Post-1945 Europe had many of the traits observed today in Eastern Europe and the Soviet Union: price controls, shortages, black markets and a monetary overhang. The policy response in most countries was monetary reform: the deliberate immobilization of liquid assets and in many instances an outright write-off of deposits. The paper revises the historical experience, notably the German reform of 1948 , identifies the policy issues involved and draw's lessons for today.
\end{abstract}

Macroeconomics becomes harder as wartime controls or outright political repression become less effective. The experience of Latin America suggests that in economies with large public sectors, politicized wage setting, a printing press and new democracy macroeconomic instability is endemic. The difficulties are vastly increased if the initial conditions leave a country with a substancial overhang of liquid public debt or money. For Eastern Europe and the Soviet Union today much is to be learned from inflation experienced in Latin America. But there are also important lessons to be gathered from the European financial experience and monetary reforms in the aftermath of World War II.

In several Eastern European countries the problem is more complicated than the standard hyperinflation scenario because, on top of the budget deficit combine with an initial monetary overhang which is sustained by price controls. Bulgaria and Roumania seem poised to experience extreme inflation once decontrol of prices, the overhang and a large budget deficit have their rendezvous. Likewise in the Soviet

I We would like to thank Stan Fischer and the participants of seminars at MIT, the NBER, and the IMF for helpful comments and suggestions. Financial support was provided by a grant from the National Science Foundation.

\begin{tabular}{|l|r|r|r|r|}
\hline ANÁlISE ECONÔMICA & ANO 9 & № 16 & SETEMBRO, 1991 & P.3-29 \\
\hline
\end{tabular}


Union, a monetary overhang and huge budget deficits financed by money creation set the stage for a potencially serious inflation.

The statistics are, of course, wide open to question, but an indication of the problem ahead is given by the size of budget deficits in the past few years. The data show persistent and increasing deficits. As comprehensive price controls remain in effect and output is falling, the monetized part of the deficit adds directly to the overhang.

Table 1 The Soviet Budget Deficit

(Percent of GNP and percent per year)

\begin{tabular}{|c|c|c|c|c|c|c|}
\hline & 1985 & 1986 & 1987 & 1988 & 1989 & $1990^{2}$ \\
\hline $\begin{array}{l}\text { Revenues } \\
\text { Spending } \\
\text { Budget Deficit }\end{array}$ & $\begin{array}{l}47.3 \\
49.7 \\
-2.4\end{array}$ & $\begin{array}{l}45.8 \\
52.0 \\
-6.2\end{array}$ & $\begin{array}{l}43.6 \\
52.0 \\
-8.4\end{array}$ & $\begin{array}{l}41.7 \\
51,0 \\
-9.2\end{array}$ & $\begin{array}{l}41.0 \\
49.5 \\
-8.5\end{array}$ & $\begin{array}{l}42.8 \\
50.6 \\
-7.9\end{array}$ \\
\hline $\begin{array}{l}\text { Retail Inffation } \\
\text { Money Incomes }\end{array}$ & $\begin{array}{l}\text { n.a } \\
\text { n.a. }\end{array}$ & $\begin{array}{l}2.0 \\
3.6\end{array}$ & $\begin{array}{l}1.3 \\
3.9\end{array}$ & $\begin{array}{l}0.6 \\
9.2\end{array}$ & $\begin{array}{r}2.0 \\
13.1\end{array}$ & $\begin{array}{r}4.8 \\
14.5\end{array}$ \\
\hline
\end{tabular}

Aplan and estimates

Source: Intermational Monetary Fund (1990)

As always in a situation of excess liquidity and controls, the question is debated whether there is in fact an overhang and, if so, just how much. In the case of the Soviet Union the estimated ratio of $\mathrm{M}_{2}$ to GDP was 72.5 percent in 1990, up from 51.2 percent in 1986.

As market forces are unleashed and controls are lifted, the monetary overhang becomes problematic and will be eliminated, by deliberate monetary reform or else by hyperinflation. Of course, monetary reform is not enough; it attends at best to the stock issue, the monetary overhang, but it does not solve the flow problem, which is the budget deficit. The flc $w$ prablem calls for the conventional budget cutting.

\section{THE ADJUSTMENT AFTER TWO WARS}

Adjustment of excess money balances can be accomplished in two ways: Fither by a one-shot inflation, or else by a reduction of effective nominal money balances. Thus money balances can be either inflated away, written off, consolidated as debt or retired by asset exchanges or budget surpluses.

A one time increase in the price level can restore equilibrium in both the goods and the money market. On quantity-theoretic grounds, the alternatives of increasing the price level and of reducing the money supply are apparently equivalent. Both succeed by lowering the real 
money supply to its equilibrium level. The short run consequences may however differ substantially. Specifically, the "blip in the price level" that removes the overhang may easily give rise to a highly unstable inflation process.

The European experience in the decade following World War II provides a fertile ground for assessing the implications of the two policy alternatives. The aftermath of World War I was characterized by "open inflation". By contrast, the post World War II environment had as initial conditions controlled prices, stagnant production and substantial idle money balances which are strikingly reminiscent of the Eastern Europe of today. $\overline{2}$ Where extreme inflation had been common in the aftermath of World War I, monetary reform was the rule following the second war.

Table 2 Post War Price Movements: 1918-1922 and 1945-1949

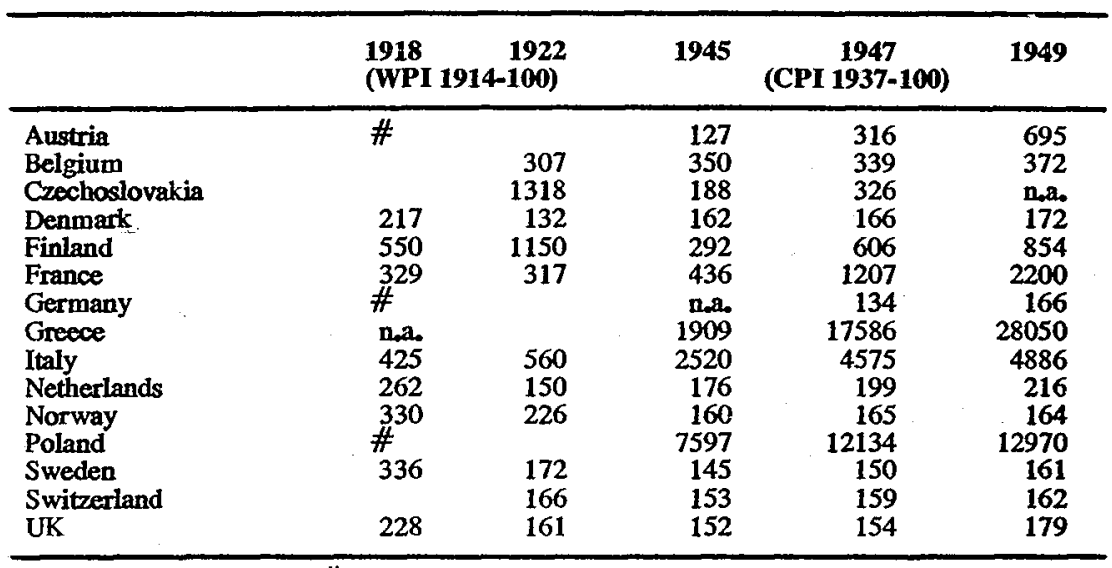

Notes: $\mathrm{n}_{-} \mathrm{a}_{0}$ - not available; \#- hyperinflation.

Source: IMF International Financial Statistics, Wirtschaftsjahrbuch 1950, Mitchell (1978), Grotius (1949a).

In the following sections, we review the conceptual issues involved in monetary reforms and discuss the historical evidence, in particular the German reform of 1948.

\section{MONETARY REFORMS IN THE 1940s.}

War finance increased the outlays of the typical European country far beyond tax revenues. As governments were reluctant to rely on extra

2 See Dornbusch and Fischer (1986) and Dornbusch, Sturzenegger and Wolf (1990) for the experience following World War I. 
taxation for reasons of morale, and debt sales, though generally successful, were rarely sufficient to cover the increased expenditure, unfunded deficits became the rule rather then the exception. As a common practice, governments relaxed regulations regarding the permissible degree of monetization for the duration of the military conflict, leading to substancial increases in the supply of money. In countries under occupation, further increases in the money supply resulted from the attempt of the occupying forces to extract support from the local economy.

\section{Table 3 Increase in Money Supply during German Occupation (percent)

\begin{tabular}{lllr}
\hline Belgium & 264 & Norway & 481 \\
Denmark & 238 & Yugoslavia & 1533 \\
Netherlands & 317 & & \\
\hline
\end{tabular}

Source: Klopstock (1946)

Price controls "'ere introduced to facilitate the military planning process and to avo.u the demoralizing consequences of the threatening rapid inflation. In combination with the rationing of scarce consumption goods as resources were shifted towards the military sector, the measures resulted in a substantial buildup of foced savings. ${ }^{3}$

At the end to the war, these accumulated funds, representing for the most part involuntarily postponed consumption rather then desired long tern savings, confronted a supply of consumption goods which remained at a low level due to war destruction and the aifficulty of converting factories back to the produciion of civilian goods. While governments continued to rely on price controls and rationing, these measures, accepted or endured during the war, became increasingly unpopular.

With the end of hostilities, countries who were liberated and those who were occupied thus faced much the same issue: how to return to financial stability and how to restore a functioning economy. Restoration of a functioning market economy was an essential step on the road to recovery, but that required liberalizing in prices which, if inflation was to be avoided, could not be risked without attending to the monetary overhang.

At the end of World War II most European countries therefore, with the important exceptions of Italy and the UK, applied a financial

3 See Klein (1956) for a comparison between Germany, Italy, Great Britain and the United States. See, too, United Nations (1948, Table 36). 
reform. Table 4 provides a summary overview of the reforms. ${ }^{4}$

Table 4 also ilustrates the predominant choice of a reduction in effective money in preference to the inflationary solution to the monetary overhang. ${ }^{5}$ Most monetary reforms differentiated according to type and magnitude of asset holdings in respect to the write-off ratio. The differentiation recognized the political objective of targeting groups that had gained, illegally or as a matter of fact, in the war period, or simply reflected the desire to share burdens on the basis of the ability to pay. An investigation of the distribution of monetary assets therefore was always an important aspect in designing monetary reform.

\section{Table 4 Monetary Reforms in the 1940s and 1950s}

\begin{tabular}{|c|c|c|c|c|c|}
\hline Country & Date & Registration & Blocking & Write-Down & $\begin{array}{l}\text { Levy or } \\
\text { Forced Loan }\end{array}$ \\
\hline \multicolumn{6}{|c|}{$\begin{array}{l}\text { NO MONETARY REFORM } \\
\text { Italy } \\
\text { UK }\end{array}$} \\
\hline $\begin{array}{l}\text { VARIOUS STY } \\
\text { MONETARY } \\
\text { Austria I } \\
\text { Austria II } \\
\text { Austria III } \\
\text { Belgium } \\
\text { Bulgaria I } \\
\text { Bulgaria II } \\
\text { Czechosl'a I } \\
\text { Czechosl'a II } \\
\text { Denmark } \\
\text { Finland } \\
\text { France I } \\
\text { France II } \\
\text { Germany (East) } \\
\text { Germany (West) } \\
\text { Hungary I } \\
\text { Netherlands } \\
\text { Norway } \\
\text { Poland I } \\
\text { Poland II } \\
\text { Rumania I } \\
\text { Rumania II } \\
\text { USSR } \\
\text { Yugoslavia }\end{array}$ & $\begin{array}{l}\text { S OF } \\
\text { ORM } \\
\text { Jul. } 1945 \\
\text { Nov. } 1945 \\
\text { Nov. } 1947 \\
\text { Oct. } 1944 \\
\text { Mar. } 1947 \\
\text { May } 1952 \\
\text { Oct. } 1945 \\
\text { Jun. } 1953 \\
\text { Jul. } 1945 \\
\text { Dec. } 1945 \\
\text { Jun. } 1945 \\
\text { Jan. } 1948 \\
\text { Jun. } 1948 \\
\text { Jun. } 1948 \\
\text { Dec. } 1945 \\
\text { Sep. } 1945 \\
\text { Sep. } 1945 \\
\text { Dec. } 1944 \\
\text { Oct. } 1950 \\
\text { Aug. } 1947 \\
\text { Jan. } 1952 \\
\text { Dec. } 1947 \\
\text { Apr. } 1945\end{array}$ & * & $\begin{array}{l}* \\
* \\
* \\
* \\
* \\
* \\
* \\
* \\
* \\
* \\
* \\
*\end{array}$ & $\begin{array}{l} \\
* \\
* \\
* \\
* \\
* \\
* \\
* \\
* \\
*\end{array}$ & $\begin{array}{l}* \\
* \\
* \\
* \\
* \\
*\end{array}$ \\
\hline $\begin{array}{l}\text { Hyperinflation } \\
\text { Greece } \\
\text { Hungary II }\end{array}$ & $\begin{array}{l}\text { Nov. } 1944 \\
\text { Aug. } 1946\end{array}$ & & . & & \\
\hline
\end{tabular}

Sources: Gurley (1953), Klopstock (1946), Pesek (1958), Ames (1954), Dieterlen and Rist (1948), Snider (1949).

4 Details are provided in the appendix. We also refer to the various references that discuss the specifics of each reform. We note in particular that monetary reform goes beyond conversions of notes and deposits since it must deal with a wide variety of debts, including public debt, insurance, rent contracts etc.

5 We restrict our attention to Europe. Japan, for example, opted for a combination of conversion, bloeking and inflation. See Cohen (1949) and Goldsmith (1983). 
We now review in more detail the alternative options of the transition to a market economy. These involve the alternatives of a price level adjustment or some form of adjustment in nominal money balances. But before moving to that discussion we review the issue of measuring the overhang.

\section{MEASURING THE OVERHANG}

The essential characteristic of a monetary overhang is the existence of a large nominal money stock relative to nominal income. Because prices are frozen and no alternative assets are available money is in fact held, but the holding is involuntary in the sense that the opening of alternative opportunities in terms of assets or spending would risk a runoff of money balances.

Consider as a guide the quantity equation:

(1) $V=P Y Y M$

where $V$ denotes velocity, $M$ the nominal money stock and $P$ and $Y$ the level of prices and of real income. During the war, the typical European country experienced a loss in output as a result of physical destruction, a substantial increase in money supply as a consequence of deficit monetization and a fairly constant price level due to more or less extensive controls. As a result, actual velocity declined substantially. As a first aproximation we take desired velocity as a constant. Seen in this light, the monetary overhang is reflected in a fall of actual relative to desired velocity. The resulting disequilibrium can be characterized equivalently as an excess supply of real money or an excess demand for commodities and other assets. The adjustment of velocities, following reforms, is shown for some countries in Table 5.

Table 5 Velocity Pre and Post-Reform

\begin{tabular}{rrrrrrrrr}
\hline \multicolumn{2}{c}{ Belgium } & \multicolumn{2}{c}{ Czechoslevakia } & \multicolumn{2}{c}{ Netherlands } & \multicolumn{2}{c}{ Germany (West) } \\
\hline \multicolumn{7}{c}{ Pre-Reform } \\
1937 & 1.52 & 1937 & 0.74 & 1937 & 1.98 & 1937 & 3.73 \\
1944 & 0.55 & 1945 & 0.32 & 1945 & 0.38 & 1948 & 0.18 \\
& & & \multicolumn{7}{c}{ Post-Reform } & & & \\
1944 & 1.58 & 1945 & 9.44 & 1945 & 1.01 & 1948 & 21.29 \\
1949 & 1.59 & 1949 & 1.83 & 1949 & 1.95 & 1949 & 4.22 \\
\hline
\end{tabular}

Source: Pesek (1958) 
One approach to measuring the overhang would be to look back to a previous period of reiative economic stability, calculate the change in nominal income that occurred since that time and assume the old level of velocity as the plausible level in a situation of decontrol. This procedure was, in fact, followed in the Netherlands as reported by Lieftinck (1973).6 That method yields an estimate of the percentage overhang: To effect the current level of transactions at the current price level and the old level of velocity requires a money stock $M^{\prime}=P Y / V_{0}$. Accordingly the percentage overhang, $M / M^{\prime}-1$ is:

$$
\lambda=\left(V_{o} M-P Y\right) / P Y
$$

But this expression may be quite misleading for a number of reasons: If monetary reform is accompanied by a decontrol of prices then there is a possibility that output could rise significantly. The increase in output would result from more productive use of resources in response to an alignment of relative prices and from a greater supply of labor effort. Increased output, as already noted, reduces the overhang. 7

Moreover, in a situation of repressed inflation there will be black markets. Prices in the black market will be part of the "effective" price level prior to monetary reform and the output traded in the black market must be included in the volume of transactions in addition to the controlled vaiue of output. Accordingly the quantity equation must be modified to allow for the possibility that the price level need not rise:

$$
M V=P_{b} Y_{b}+P_{c} Y_{c}
$$

Black market prices might fall (certainly in relative terms) and thus offset to some extent the rise in controlled prices.

A conceptual approach to measuring the overhang starts with a non-market-clearing model of the economy such as Barro and Grossman (1976). Because markets do not clear, complicetions include the effect of rationing on labor supply, the diversion of resources to the black market and the effects on labor supply and on spending of anticipated changes in the rationing scheme over time. The particular specification of tastes and technology will shape the results.

The expectation of an (eventually unavoidable) monetary reform might reduce the demand for real balances as money holders shift into black market goods, financial asset or dollars; thereby increasing the monetary overhang. The German stock market, to take an example,

6 See, too, Holtzman (1974) for the case of the Soviet Union.

7 There are also once and for all effects: a reduced hoarding demand for scarce goods and a sell-off from inventories by firms who have beld goods as a speculative asset. Of course, these are not recurrent and hence cannot affect the long run price level. 
experienced a substantial boom during the "dismal years" 1945-1948. Once the likelihood of reform becomes a certainty, the flight into real assets becomes intensified. In the last week before the German currency reform the black market prices for cigarettes increased tenfold from 5 to $50 \mathrm{RM}$, the dollar traded for up to 1000 Mark, (Neue Zurcher, 21.6.1948). But the effect is not altogether clear-cut: black market prices for dollars might already reflect a significant premium and securities would be risky because of the possibility of capital levies. 8

Also, in a situation of shortages the public might wish to hold unusually large balances to take advantage of opportunities to purchase goods, should they be found accidentally. Thus there is a "precautionary" demand that is artificially enlarged by the disruption of markets. It seems, however, that in the face of the possibility of monetary reform and major write-ofts this precautionary demand was met by cigarettes rather than money. 9

The upshot of this discussion is that there is no clear-cut way to judge what would be the write-off in nominal money balances that maintains the initial level of controlled prices as the equilibrium level. The question therefore arises as to the relative merits of a "soft" versus a "hard" reform. If the write-off is insufficient either inflation emerges or continued control becomes necessary, with the prospect of a future write-off which in turn aggravates distortions. If the monetary reform includes the introduction of a new currency, a perceived insufficiency of the accompanying fiscal measures may also adversely affect the public acceptance of the new money.

Aternatively, a write-off which errs on the conservative side allows the government to gain seigniorage from a one-time money issue. An excessive squeeze might also be motivated by a desire to leave firms highly illiquid so that they would be forced to sell off inventories, thereby increasing the current effective supply of goods. This argument was used in the German reform of 1948 to limit the initial cash allocations to firms.

\section{DEALING WITH THE OVERHANG}

The resolution of the monetary overhang requires either an increase in real money demand or else a reduction in the nominal money

8 Some evidence on the anticipation of monetary reform in Germany, for example, is available. The exchange rate of the Swiss Franc (SF/100 MR) moved from 1.62 to 1.9 in the period January to May 1948 before declining to 1.25 in the fimal month before the reform. Interestingly, the rise falls far short of the actual write-off on German monetary assets.

9 See Guggenheim (1965) and Wirtschaftsspiegel (1948). 
stock. There are seven alternative mechanisms to restore monetary equilibrium:

1. An increase in the level of output, at the prevailing level of prices (but with an adjustment in relative prices, if necessary). The experience of the 1940s suggests however that adjustment of the financial sector, possibly through monetary reform, may be a precondition for the recovery of output.

2. A decrease in desired velocity, at given prices, money and output. The question arises whether demand for long term saving accounts is sufficiently elastic with respet to the available policy instruments, in particular the interest rate, to make this channel feasible for any but the smallest disequilibria.

3. A rise in the price level, by fiat or by market forces. In principle this only needs to be a "blip" in the price level. In practice it might become open inflation, as in postwar Italy or France, or worse, uncontrolled inflation.

4. The retirment of the overhang over time by budget surpluses.

The remaining alternative is a reduction of the nominal money supply. This could take one of two +forms:

5. A blocking of nominal assets that immobilizes a portion of the monetary holdings.

6. Conversion of monetary assets (or of all nominal assets) held by the public into new intruments, or 10

7. A uniform or differentiated write-down of monetary assets.

Furthermore, it is important to know whether conversion of monetary assets into interest bearing liabilities is feasible once it is recognized that the asset side of the banks' balance sheet is in serious trouble. An alternative, of course, is the tie-in of financial reform with public sector asset sales. 11

Neither of the "easy options" - an increase in output or a suostantial fall in desired velocity - is likely to cure but the mildest case of monetary overhang. Nor will there be budget surpluses on a scaic to solve the proolem. The realistic choice faced by governments comes down to accepting a period, however brief, of rapid inflation or to a reduction in the effective money supply. We now consider these options in turn.

10 Curency conversion includes as a special possibility the recent conversion effected in East Germany in the context of the 1990 monetary unification. See Bofinger (1990) and Wolf (1990).

$11 \mathrm{~A}$ particularly interesting precedent is the Belgian reform in the $1920 \mathrm{~s}$. Facing funding crisis on an overhang of overly liquid debt the government converted the debt claims into ownership certificates in the wational railrosd. Shepherd (1936) reports that the bond holders came out ahead. 


\section{A. INFLATION}

The only feasible alternative to reducing the effective nominal money supply is an increase in the price level. From a theoretical point of view, both policies are equivalent: whether the excess supply of real money balances is cured by a decrease in nominal money or a one time increase in the price level is irrelevant.

In practice, economies with a monetary overhang face a dual problem. On the one hand, equilibrium on the money market requires an adjustment of the absolute price level. On the other hand, an alteration in the typically distorted relative price structure is necessary to restore goods market equilibrium. In the presence of some indexation and implicit agreements, adjustment will not come as a blip in the price level but as a more or less protracted period of high inflation.12

High inflation in turn, may feed upon itself. Two effects are of particular importance.13 Inflation tends to reduce the real value of taxes. In the absence of additional revenue sources, the solution of the stock problem may thus give rise to a flow problem as the increased deficit is monetized. Furthermore, as inflation accelerates economic institutions adjust to the new environment. In financial markets, the introduction of indexed assets combined with the gradual replacement of currency as viable medium of exchange further increases desired velocity. In the goods and factor markets, payment arrangements shift towards more frequent adjustment, enhancing the economy's sensitivity to future inflationary shocks.

While the importance of these factors will of course vary across economies, the potential for economic catastrophe cannot be denied: Of the countries which have opted for the inflationary solution in preference to a reduction in effective money, Hungary and Greece lead the all-time hyperinflation hit list.14 Italy and France, with more limited inflation, still experienced a vast rise in prices. In Italy, between 1945 and 1949 the price level doubled and in France it increased fivefold.

\section{B. REDUCING NOMINAL MONEY}

We can distinguish three basic types of monetary reform: The first is a mere change of numeraire. In this reform a new currency is issued

12 From a policy point of view a number of steps, in particular an adjustment of the relative price structure by decree prior to the unfreezing of prices and a mandatory renegotiating on long term constracts at the time of the reform, can be undertaken to reduce if not eliminate the importance of factors leading to protracted inflation.

13 See Dornbusch, Sturzenegger and Wolf (1990) for a detailed description of these feedback channels.

14 In the case of Greece civil war was, of course, a decisive factor in the hyperinflation. 
with full conversion of the old currency into the new one. The purpose of the conversion would be to eliminate a number of zeros.15 It might also help determine the wealth distribution with a view towards later taxation or to eliminate illegally acquired currency hoards. 16 But the essence of this reform is that in itself it has no real effects, except possibly to signal that no further actions shoulds be expected. This is clear because the new monetary unit applies to all nominal stocks and flows, i.e. it extends to currency, accounts, debt, wages and prices.

The second kind of reform immobilizes money holdings for a specified or for an unknown period by blocking bank accounts. The measure is in essence temporary; either the assets are subsequently unfrozen or else the measure ends in a later write-off of the frozen assets or a (forced) conversion into interest bearing non-marketable loans. In the latter case an upper bound on the converted assets might be set with regard to political objectives. Being forced, the interest rate on the conversion would be at the discretion of the government, thus avoiding the difficulty that arises in a voluntary conversion where lack of credibility translates into potentially extravagant interest rate burdens.

The consolidation strategy creates a debt for which the government may not have the fiscal service capacity. This is particularly true in the aftermath of a war where tax yields may be small and reconstruction spending is large. A write-off of nominal assets in such a situation may clear the ground for the issue of a public debt whereas respect of old money and debts would simply overburden public finance and thus the credibility of further debt finance.

The Soviet Union and Eastern Europe today offer a special opportunity. Unlike in the case of Europe in the immediate aftermath of the war, in these countries the physical capital stock, while in a sad state, is still in existence and is in the hands of the government as is the banking system. A possibility therefore exists of combiniug cancellation of interfirm debts, privatization of assets and monetary reform.

The third kind of monetary reform is confiscatory: currency and/or bank accounts are written off a uniform conversion rate or on a differentiated basis. Here the conversion is not merely nominal but real: money balances are converted at a less favorable rate than flows such as rents or wages. A uniform conversion of all nominal assets held by the

15 In the $1980-90$ period Brazil, for example, changed its currency five times.

16 This first of these motives figures prominently in the Argentinean and Brazilian reform cycles. The second was of considerable importance in the post WWII reforms, notably 80 in the Scandinavian countries. The third motive played a subsidiary role in virtually all post WWII monetary reforms, regardless of the type. In the 1948 reform in Germany, for example, the conversion of deposits above 5000 MR required prior authorization from the fiscal authorities. 
public is equivalent to a blip in the price level and thus has the same distribution effects. A more differentiated process can accommodate desired political features such as the special taxation of speculators (who hold large amounts of currency) or of affluent groups (who hold government debt and large deposits).

Blocking assets in preference to outright conversion preserves the option of releasing funds later, without inflationary consequences, if economic 'conditions are revealed to be better then antecipated. Thus blocking at best replaces, at worst postpones the politically unpopular wealth tax. It is interesting to note in this context that almost all of the countries finally opting for a conversion did not have a democratically elected government at the time of monetary reform. In constrast, most democracies opted for blocking in preference to conversion.

The choice between blocking and conversion is determined by a number of considerations: First, the monetary overhang spills over into demand. Once quantity controls are lifted, the demand for consumption goods derives from a flow component representing the flow income accruing to consumers and a stock component reflecting the desire of asset holders to exchange part of their monetary wealth for goods. As the flow income bears a rough relationship with the flow of newly produced goods, it is the stock adjustment that gives rise to the inflationary pressure.

Conversion, works by reducing consumer's asset holdings to the desired level, given current prices and income flows. Blocking, on the other hand, operates by limiting the extent to which the desired substitution from monetary wealth to commodities can take place. The two strategies differ in the marginal propensity to consume out of an equal amount of unrestricted asset holdings: at least a certain proportion of the blocked assets continues to be treated as real wealth which will become available at some time in the future. In consequence, the propensity to consume out of the free accounts will be higher in the case of blocking then in the case of conversiou. To achieve the same effect on consumption, ceteris paribus, the blocking ratio must exceed the conversion ratio.

Second, conversion places holders of monetary wealth at a disadvantage vis a vis holders of real assets. The resulting political conflict has often been addressed by subsequent real wealth levies aimed at the equalization of the burden or reform.

Thid, decisions about write-offs have to be considered in the context of the balance sheets of financial institutions. If the assets are non-performing, because of physical destruction of collateral, loss of territory or otherwise, there is simply no reasonable way of sustaining the liabilities. Of course, the government could guarantee the liabilities 
and place net worth certificates serviced out of general revenues in bank balance sheets, but this would evidently place a major burden on public finance unless there is a tie-in with other operations such as privatization or external loans.

Fourth, monetary reform has a special significance if it risks impairing the assets of potential buyers of state enterprises. One view in the debate holds that write-offs impair the growth prospects of the emerging market economy: if large deposits are written off, their holders, who are the most likely candidates to run capitalism, would as a result be unable to participate in a buy-out of the public sector firms. Of course, this argument places much weight on the initial distribution of assets as indicating capitalistic ability and it implicitly assumes that buy-out rather than giveaway is the best means of privatization.

Conversion and blocking are of course not mutually exclusive. Given a guesstimate of the size of the overhang and of the likely recovery of output, the combination of a generous conversion rate with a substantial blocking permits the government to adopt a wait and see attitude: If the initial guesses turn out to be correct ex post, ine blocked funds can be released and the original generous conversion rate maintains. If events take a less positive turn, a conversion of the blocked assets lowers the original conversion rate to a level more consistent with price level stability.

In the following section we provide a brief discussion of the West German case, both as an illustrative example of the buildup and eventual elimination of a monetary overhang and as a case study of the relation between monetary reform and real performance.

\section{MONETARY REFORM IN GERMANY}

The currency reform in the occupied German Tri-Zone on June, 20th 1948 marked the beginning of the "German Economic Miracle". In the five months directly following the reform, industrial output increased by more then fifty percent. Over the period 1947-49 it more than doubled, a ravaged, apparently moribund economy regained its health overnight. Furthermore, the strong growth performance was not restricted to an initial rebounding but continued well into the $1950 \mathrm{~s}$. The timing coincidence of currency reform and economic takeoff raises the issue of the role of the 1948 monetary reform in the economic miracle.

\section{A. BACKGROUND17}

Fiscal and monetary policy in the Third Reich were completely

17 For a more detailed description, see Lutz (1949), Hielscher (1949), Moller (1961), and the references given therein. 
subjugated to the war effort, the "noiseless financing" of the rearmament process being the proclaimed objective of the government.18 A resolution of the resulting inequities and inefficiencies was to await the end of military conflict. The shift of resources from the civilian to the military sector resulted in increasing shortages of consumption goods, culminating in 1939 with the imposition of extensive rationing of consumption goods. Coupled with continued high employment and slightly increasing nominal wages, upwand pressure on prices emerged as early as $1935 / 36.19$

Regarding inflation as detrimental to morale, the government introduced a virtually complete price freeze in 1936, followed by a wage freeze in 1938. The controls proved fairly effoctive, slowing the official inflation rate to an average of $1.5 \%$ over the period 1936 to 1944.20

As the war progressed, consumption was limited to the rationed quantities of necessities being made available at the controlled prices. The difference between the fixed nominal incomes and the consumption expenditures were accumulated as "forced savings". Lacking alternatives, these funds found their way to the commercial banks who in turn invested them in public debt instruments, allowing the government to cover part of its substantial primary deficit.21 The larger part of the deficit was however financed by money creation, as Table 6 illustrates. Debt and deficits grew year after year.

Table 6 Nominal Narrow Money and Debt in Germany 1937/45 (Index 1933 -100)

\begin{tabular}{lrrr}
\hline & 1937 & 1939 & 1944 \\
\hline Money & 151 & 324 & 1375 \\
Debt & 220 & 441 & 2708 \\
Prices & 106 & 107 & 120 \\
\hline
\end{tabular}

End of December.

Source: Veit (1961) Statistisches Handbuch von Deutschland 1928-1944

18 Restrictions on the gold and foreign currency coverage of the note issue were lifted in 1933 , leaving a formal coverage requirement in form of three month treasury bills and some forms of commercial paper. See Klein (1956).

19 Industrial production (1932-100) increased to 175 by 1936 and 203 by 1939 . See Klein (1956).

20 See however Klein (1956) who argues that the official index was artificially low. Calculating an implicit price index, he finds the average annual inflation rate to be closer to $4.6 \%$.

21 New capital issues were restricted in 1933. Part of the additional savings went into the stock market, generating a mini boom from 1939 to 1941 . After the imposition of a price freeze on stock markets in 1943 saving deposits formed the only remaining interest bearing asset available to the public. 
As the Third Reich dissolved, a major portion of the commercial bank assets became non-performing. While insolvent, banks remained liquid.22 Effective consumption continued to be limited to the rations available at controlled prices. Lacking alternatives, the public continued to hold their idle balances in deposits.

In the face of increasing supply shortages the military governments decided to maintain price and wage controls in place. However, the Allies failed to elicit private sector supplies as sellers refused to part with their goods in exchange for RM at the controlled prices. Rather, exchange activity took place on black markets at prices frenquently exceeding official prices by a factor of 100 and more. Similarly, firms resorted to barter in preference to monetary exchange. The combination of the wage freeze and the absence of consumption goods at controlled prices made leisure and black market activity a popular alternative to paid work. 23 In order to attract workers, firms increasingly shifted to payment in kind.

As the belief in an eventual substantial cut in RM holdings became widespread, the proportion of transactions undertaken in Reichsmark dropped precipitously, in the end being limited to the purchase of rationed goods and the repayment of debt. 24 In effect, the cigarette replaced the RM as medium of exchange as well as store of value. $25 \mathrm{By}$ early 1948, the RM had ceased to function effectively as medium of exchange.

Table 7 Ratio of Black Market to Official Prices: Germany 1948

\begin{tabular}{|c|c|c|c|c|c|c|c|}
\hline & \multicolumn{2}{|c|}{ Pre-Reform } & \multicolumn{2}{|c|}{ Post-Reform } & \multirow[b]{2}{*}{15.8} & \multirow[b]{2}{*}{15.9} & \multirow[b]{2}{*}{15.10} \\
\hline & 15.5 & 19.6 & 30.6 & 15.7 & & & \\
\hline Rye Bread & 27.1 & 45.7 & 3.2 & 2.9 & 2.8 & 2.2 & 2.5 \\
\hline White Sugar & 33.9 & 135.5 & 5.1 & 4.6 & 4.2 & 4.4 & 4.7 \\
\hline Butter & 133.3 & 195.3 & 4.3 & 4.6 & 4.4 & 4.6 & 5.8 \\
\hline \multicolumn{8}{|l|}{ Cigarettes } \\
\hline American & 20.0 & 133.3 & 1.0 & 1.3 & 1.3 & 1.3 & 1.3 \\
\hline German & 12.5 & 93.8 & 1.3 & 1.3 & 1.3 & 1.1 & 1.8 \\
\hline
\end{tabular}

Source: Mendershausen (1949)

22 Paying taxes and the repayment of liabilities remained some of the few options available to holders of RM balances. As the eventual conversion of these holdings became more likely, the private sector used idle holdings to reduce outstanding debt. As a result, the claims of the commercial banking sector on the private sector declined significantly.

23 In 1947-48, the average hourly wage amounted to 0.95 RM. At the same time, a single cigarette traded for $7 \mathrm{RM}$ and a kilogram of butter for $900 \mathrm{RM}$ on the black market.

24 See, for example, Neue Zurcher, 21.6.1948.

25 See Neue Zurcher, 21.6.1948 and Schmolders (undated) 
The breakdown of the monetary system affected industrial production more severely then consumption. Black markets in staple foods became widespread and increasingly tolerated by the military authorities. The diversified needs on the production side proved more difficult to satisfy in a barter environment, the necessity to establish a multiple coincidence of wants hampered production. As a consequence, industrial output, after an initial rebound from the minimal levels reached in the final months of the war, essentially flattened out in mid 1947 at roughly $50 \%$ of the prewar level. 26

Between 1945 and 1948 more than 100 programs of currency reform were published. Experiences throughout Europe had already demonstrated how an overhang might be consolidated or at least immobilized. Finally it was the turn of Germany to undergo an already widely expected reform.

\section{B. SUCCESSFUL REFORM}

The dismal economic situation, in conjunction with the developing strains between the Soviet Union and the Western Allies prompted the US and the UK military government to drop its previous insistence on all German monetary reform and to develop plans for a currency reform in the Tri-Zone.

This reform was implemented in the American, British and French occupied zones in June, 1948. The main provisions of the reform are given in Table 8.

26 The statistics based on reported output place a large weight on the production of large enterprises. It is likely that some unreported production "for the shelves" in anticipation of a future return to normal monetary circumstances has taken place. Abelshauser (1977) argues on the basis of energy consumption statistics that output in fact continued to increase throughout 1947. See however Buchheim (1989) and Ritschl (1985) for a critical assessment of the revisionist view. 
1. Individuals and firms were issued in two instalments a per capita allowance, C,M 60 per person and DM 60 per worker for firms. The public sector also received an initial allowance.

2. Half of deposits were converted at the rate of 10:1 into deposits, the other half blocked. Subsenquently, 70 percent of the blocked accounts was written off and of the remainder two-thirds were placed in free accounts and one-third into blocked investment accounts.

3. With few exceptions, all flow magnitudes, in particular wages, were converted at $1: 1$.

4. In contrast to holdings of the private sector, intra-bank RM claims, RM claims against the Third Reich (including public debt) and RM holdings of the public sector were canceled.

5. Commercial Banks were granted claims against the Lander, accepted at the Bank Deutscher Lander, to cover the shortfall of assets relative to liabilities due to the cancellation of government debt.

6. The Deutsche Mark was declared sole legal tender. The Bank Deutscher Lander, acting as central bank, was entitled to impose minimum reserve requirements. The total note issue was limited, the limit could only be raised with the consent of a qualified majority of the Lander.

7. The budget was required to be balanced by law.

Table 9 shows the resulting evolution of the initial allocations and the conversions.

Table 9 Initial Allocation and Conversion (Stock of DM, billion)

\section{8}

1949

June Sept. Dec. March Dec.

\begin{tabular}{|c|c|c|c|c|c|}
\hline \multicolumn{6}{|l|}{ Initial Allocation } \\
\hline Public Autorities & 2.5 & 3.45 & 3.4 .5 & 3.45 & 3.45 \\
\hline Persons and Firms & 1.9 & 3.25 & 3.25 & 3.25 & 3.25 \\
\hline \multicolumn{6}{|c|}{ Conversion of Deposits } \\
\hline Free Accounts & - & 3.5 & 5.3 & 5.7 & 6.2 \\
\hline Blocked Accounts & - & 2.85 & $0.75 \mathrm{a}$ & 0.55 & 0.35 \\
\hline
\end{tabular}

a Effect of cancelling 70 percent of blocked deposits.

Source: Bank Deutscher Lander (1950). 
Just as the Rentenmark in the 1923 reform, the Deutsche Mark found rapid acceptance. Hoarded inventories were offered fo sale against DM starting the day after the reform. The instantaneous acceptance of the new currency before the sufficiency of the monetary cut could be assessed stresses the prime importance of broad popular support for the reform. Such support derived on the one hand from the desire to return to a functioning monetary system of exchange, on the other hand from the perceived decisiveness of the reform announced to attain that goal.

The actual rate of conversion might matter less then the perceived determination of the authorities to carry the program through. Indeed, L. Tenenbaum, the US liaison officer with the German stabilization team, stressed that a bold reform with an, ex post, incorrect conversion rate might well be preferable to a timid conversion at the, ex post, appropriate rate. 27 In Germany, the initial conversion took place at a rate of $10 \mathrm{RM}$ to $1 \mathrm{DM}$, with half of the converted funds blocked and only released partially in the end. As Table 10 and Figure 1 illustrate, this rate, ex post, indeed turned out to be too generous: the half year following the reform was marred by some inflation.

\section{Table 10 Money Supply and Exchange Rate in Germany}

\begin{tabular}{rccc}
\hline $\begin{array}{c}\text { Cost of Living } \\
(\mathbf{1 9 3 8 - 1 0 0 )}\end{array}$ & $\begin{array}{c}\text { Material Prices } \\
(\mathbf{1 9 3 8 - 1 0 0 )}\end{array}$ & $\begin{array}{c}\text { Free Exchange rate } \\
\text { Swiss Francs/100 DM }\end{array}$ \\
7.48 & 152 & 159 & 35 \\
12.48 & 168 & 193 & 19.5 \\
4.49 & 164 & 187 & 60.5 \\
\hline
\end{tabular}

Source: Bank for International Settlements Anual Report 1949, Grotius (1949b)

The availability of the blocked accounts provided the authorities with a means to fine-tune after the response of the economy to the initial reform became known. Responding to the inflation, $70 \%$ of the blocked accounts were canceled in a second step, with $20 \%$ being released and $10 \%$ continued to be blocked for later conversion into interest bearing assets. The negative wealth effect, combined with restrictive credit policy, dominated the liquidity effect from the additional released funds,

27 Few monetary reforms occur without decisive intervention and the driving force of a key personality, be it foreign or national. Razin played the role in Czechoslovakia, Schacht in Germany in 1923, Edwin Kemmerer throughout the world in the interwar period. In Germany's case US Lt. Tenenbaum may bave been that key person, though his role remains unappreciated. See Bennett (1950) and Richter (1979). 
prices stabilized at year end. The success of the reform is mirrored in the decline of the black market premium.

By 1950 Bank Deutscher Lander (1950, p.2) could appraise the gain in confidence as follows:

"Even the public, in spite of the heavy jolts which the Currency Reform gave to the holders of assets in monetary form for the second time in one generation, have to a large extent regained their confidence in money. Savings are increasing to a remarkable extent. Foreigners also have increasing confidence in the German currency, as is shown by the rise in the quotation of the DM on certain free markets abroad."

Among the factors responsible for this gain in confidence were certainly the following three. First, the monetary reform made money tight and credit policies did not reverse that result. Second, the public accounts were not only balanced, they even showed a surplus. Under the strict rules set by the occupation forces, and subsequently by the new constitution, the budget was required to be balanced and in fact it was.28 Third, a critical measure accompanying monetary reform was the substantial dismantling of controls. With the exception of controls and rationing for some basic materials and food, and of substantially all foreign transactions, prices were freed. Table 7 above showed the decline even in black market price ratios for goods that continued to be controlled. While foreign trade transactions were progressively liberalized, exchange control did continue into the early 1950 s on a substantial scale. Convertibility was slow to come about.

On the real side, there is no shortage of stories about the immediate, dramatic effects on economic activity unleashed by the monetary reform and price liberalization. Prior to the reform, absenteeism had been the rule. From December 1947 to May 1948 absenteeism averaged 14.7 percent ot the work force. After the reform, it fell off to 9.6 percent in June 1948 and 6.3 percent in July 1948.29

The strong increase in industrial production and economic activity is brought out in Figure 1. On the basis 1936-100 the index of production stood in June 1948 at 51 . By the end of the year it had reached 79 and in April 1949 it had climbed to 89. Of course, these numbers must be judged with some caution. During the period of complete control and rationing production may have taken place already, but not officially recorded as goods were diverted to the gray market for barter. Even so, there is little doubt that the liberalization made a decisive contribution to the productivity of the economy. The rapid

28 See Reuss (1963), Hansen and Musgrave (1951), and Bank Deutscher Lander (1950).

29 See Guggenheim (1965) p.37. 
expansion in output over the next three years was sustained, after some time, by a strong growth in real wages, generating the flow demand.

While monetary reform and price decontrol are important as critical preconditions of the "economic miracle", continued growth depended on a number of real factors, in particular the substantial fiscal measures implemented in conjunction with the monetary reform. The occupation powers had raised marginal tax rates even beyond the extremely high rates of the war period. In the process of liberalization accompanying the monetary reform these tax rates were cut substantially, especially for the middle class. 30

\section{GERMAN INDUSTRIAL PRODUCTION (Index 1936-100)}

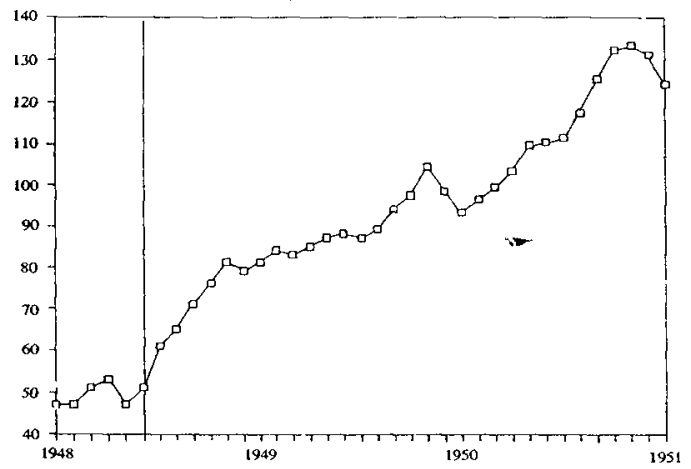

GERMAN COST OF LIVING (Index 1938-100)

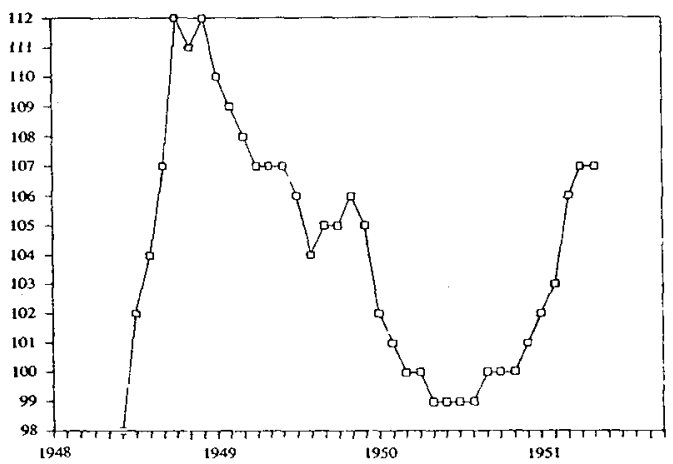

30 The average income in 1948 was about DM 1,000. For the income bracket of DM 1,200 to 2,400 , the marginal tax rate was cut from the 1946 level of 25 percent to 18 percent. In the next bracket $(2,400-3,600)$ the rate was cut from 50 to 24 percent. But the upper rates remained extremely high with the top marginal rate at 95 percent. For details see Heller (1949). 
Supplementing decontrol as well as monetary and fiscal reform the government undertook further steps along an explicitly pro-growth, pro-market strategy to revive the economy and restore prosperity. Among the characteristics of West German economic policies over the post reform years, a determinedly conservative fiscal policy assumed particular importance. In addition to freeing resources for private and public investment, the government further stimulated investment by substantial investiment tax credits and subsidies.

The "economic miracle" derived further support from the availability of skilled labor. More than 10 million refugees streamed in from the East, making for a substantial labor supply and a wage brake. A high domestic savings rate coupled with capital inflows from the Marshall plan provided the resources for a substantial expansion in investment. But it is important to emphasize that monetary and fiscal reform and price liberalization were the primary vehicles for recovery, Marshall aid came to play a crucial role in sustaining the momentum and avoiding early bottlenecks.

In conclusion, there is little doubt that the German reconstruction measures of 1948 involved hardship. But what were the alternatives? And did not the subsequent economic performance warrant the initial investment in decisive measures?

\section{AFTER THE REFORMS}

In the period 1948-59 all of Europe rebuilt their economies, gradually reestablished financial systems and liberalized, step by step, external trade and payments. European convertibility came early, but full multilateral convertibility was mostly attained by 1958 , though some countries, in particular France and the UK took much longer to reach that goal. Considering the relatively uniform starting conditions countries and the homogeneity of monetary reforms illustrated above, the markedly different performance of these economies over the ensuing decade is striking.

While Austria, Germany and Italy experienced rapid growth, others, notably Britain, did quite poorly. The absence of a clear cut correlation between the severity of the wealth tax imposed in the course of monetary reform and the subsequent growth performance raises two issues. First, it provides suggestive evidence against the view that conversion, by reducing the assets of the potential capitalists, lowers the attainable growth rate. Secondly, it raises the question which factors can explain the divergent performance record. Two issues raised in this respect are the importance of economic philosophies and the contribution of external aid in the form of the Marshall Plan. 
Very different economic philosophies were applied; while Britain, France, Scandinavia and the Netherlands favored intervention, Erhardt in Germany and Einaudi in Italy preached and (to a somewhat lesser extent) practiced market-oriented policies. 31

The end of World War II found all European countries faced with the need for external finance to rebuild their ravaged economies. The willingness of the United States, as the sole surplus country, to provide funds may have been critical in providing support for the European post war boom, both by previding means to acquire raw materials and by generating an intra-European demand boost. ${ }^{32}$

Table 11 - Marshall Aid July 1948 - June 1949

\begin{tabular}{lcc}
\hline Country & $\begin{array}{c}\text { Net total aid } \\
\text { Million \$ }\end{array}$ & $\begin{array}{c}\text { Ratio } \\
\%\end{array}$ \\
\hline Austria & 279 & 14.0 \\
Belgium/Lux. & 40 & 0.6 \\
Denmark & 116 & 3.3 \\
France & 1.304 & 6.5 \\
Germany (Tri) & 501 & 2.9 \\
Greece & 212 & 14.1 \\
Iceland & 5 & 5.0 \\
Ireland & 78 & 7.8 \\
Italy & 535 & 5.3 \\
Netherlands & 541 & 10.8 \\
Norway & 115 & 5.8 \\
Sweden & 22 & 0.3 \\
United Kingdom & 949 & 2.4 \\
Total ERP & 4.743 & 3.8 \\
USA & 4.743 & 2.1 \\
\hline
\end{tabular}

Source: BIS, Nineteenth Annual Report 1949, p.20

Each of these questions is relevant to the experience of Eastern Europe and the Soviet Union today. The presumption flowing from the experience of the postwar stabilizations might be summarized as follows:

First, monetary reform is an alternative to high and possibly hyperinflation. It can be a sound ingredient in economic reconstruction

31 See Stolper and Roskamp (1976), Hunold (1953) and Denton, Forsyth and Maclennan (1968) on this point.

32 See Moller (1989), Milward (1984) and Kaplan and Schleiminger (1989). 
or conversion to a market economy. It avoids burdening a difficult adjustment phase with unnecessary macroeconomic complications. But monetary reform only deals with balance sheets. Success requires a fiscal policy solving the flow problem.

Second, monetary reform may not be necessary and surely is not sufficient for success. Countries who did not have a monetary reform, for example Italy, did perform well after inflation had been brought under control. (Of course, the inflation did liquidate the government debt.) Other countries who did administer a reform performed quite poorly. It is tempting to avoid the political difficulty of a write-off, but if there is a risk of hyperinflation monetary reform is the better bet. But monetary reform is not enough. Serious supply side policy, in particular on the tax front, facilitates the transformation from planning to the market. In addition, external aid will help reconstruction and may be an essential ingredient in stabilization.

Third, high saving rates by the private sector are a critical ingredient in reconstruction. Surely a write-down of a financial overhang seems a far more conducive strategy to enhance private saving than large transfers associated with a consolidation of the overhang into interest debt or a situation of inflation where the flight from money is the rule, even if in the aggregate it is self-defeating.

Fourth, monetary reform, because it involves blocking or writing-down of assets is throughly unpopular. But dismissing the measure out of hand simply because of its unpopularity is foolish; one has to evaluate the alternatives. Massive taxation to reverse a monetary overhang by budget surpluses is presumably as unpopular and administratively less feasible. Contrulled inflation is difficult to achieve and uncontrolled inflation, possibly extreme inflation, surely does not win in a contest of favorite measures.

Policy makers must focus realistically on alternatives and once that is done, monetary reform may appear a sound option in quite a few situations. The argument that it weakens confidence just at a time where confidence is so essential must be rejected. Confidence depends on the future ability and willingness of a government to meet its commitments. Governments who have eliminated an overhang of money or debt will look better than governments who appear willing to honor their liabilities but are patently unable to do so. Against the illusion of easy solutions we hold the advice of W. Vocke, the first President of the postwar German Central Bank: "Soft measures don't create hard currencies." 


\section{APPENDIX I. OVER VIEW OF MONETARY REFORM}

Austria 7.1945,11.1945,11.1947

New national currency (shilling). Sizable portion of currency and bank deposits blocked. Withdrawal for wage payments allowed. Account to account transfers allowed. Initial reform failed due to monetization of budget deficit. In 1947, conversion of currency and deposits at $1: 3$

Belgium 10.1944.

Blocking of currency and bank accounts. Withdrawal for wage payments allowed. Capital levy and war profit taxes imposed. Frozen accounts converted into forced loans. Anti inflationary intent failed as expenses for Allied army were monetized.

Bulgaria 3.1947 and 5.1952

Partial blocking of currency and deposits. In the conversion, holdings of private business treated unfavorably. Second reform closely modelled on Soviet example.

Czechoslovakia 10.1945 and 6.1953

New currency (Crown) introduced. Sizable part of money supply blocked. Withdrawal possible for wage payment. Progressive war gains tax and capital levy. No discernible effect on inflation. Second reform closely modelled on Soviet example and successful.

Denmark 7:1945

Partial blocking of currency and deposits for three months. Information gathering about asset distribution main objective of blocking.

Virtually all funds unblocked. Later impositon of war geins tax and forced loan.

Finland 1.1946

No blocking of deposits. Banknotes above 100 Finmark cut into two halves, one serving as legal tender at one half the denomination, the other as nonnegotiable government bond. Only $8 \%$ of money supply affected. Virtually all funds later unblocked. Little success in curbing inflation.

France 6.1945 and 1.1948

Partial blocking of large notes. Registration of money holdings; liberalization loan. Virtually all blocked funds returned.

No restraining effect on inflation. Writedown and partial blocking. Price controls continued.

Germany (West) 6.1948

Writedown at 1:10 and blocking of deposits. Later further writedown.

Prices and wages freed.

Greece 11.1944

Conversion at 50 billion tn one in midst of hyperinflation. No budgetary adjustment. No success in halting inflation.

Hungaicy 12.1945 aind 8.1946

Initial conversion of currency at $\leftarrow$ io 1 proved unsuccessful un light of continued deficit

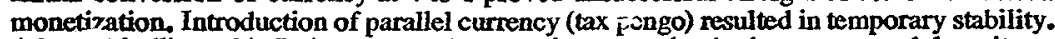
After rekindling of inflation a second conversion, covering both curnency and deposits, at 400 octillion to one, succeeded in terminating the hyperinflation.

Netherlands 6.1945 and 9.1945

Notes above 100 Guilder ceased to be legal tender but could be deposited in bank accounts which were then blocked, except for tax and wage payments allowed. Account to account payments allowed.

Inducement to convert blocked balances into 50 year bonds. Later partial blocking of remaining currency and all bank deposits. War profits taxes and capital levy.

Norway 9.1945

Partial blocking of tnoney supply. Determination of asset distribution main objective. Later imposition of war profit tax and forced loan.

Poland 12.1944 and 10.1950

Occupation moneys exchanged into new currency (zloty). Excess currency holdings blocked. Second reform modelled on Soviet example.

Rumania 8.1947 and 1.1952

Modelled on the Soviet example. Bank deposits favored vis-a-vis currency. Price and wage structure revised and lowered. 
USSR 12.1947

Conversion rate depended upon amount exchanged. Deposits favored relative to currency.

Formed the role model for the monetary reforms in Eastern Europe.

Yugoslavia 4.1945

Occupation moneys partially exchanged for dinars. Additional currency holdings and bank deposits blocked. Capital levy on monetary wealth.

\section{REFERENCES}

ABELSHAUER, W. Die Rekonstruktion der Westdeutchen Wirtschaft und die Rolle der Besatzungspolitik. In: SCHARF, C. \& SCHROEDER, H. (eds.) Politsche and Okonomische Stabilisierung Westdeutschlands 1945-1949. Wiesbaden, 1977.

- Wiederaufbau vor dem Marshall-Plan. Viertel jahreshefte fur Zeitgeschichte. $29,1981$.

AMES, E. Soviet Bloc Currency Conversions. American Economic Review. v. 44, n. 3, p. 339-53, June 1954.

BAFFI, P. Monetary Developments in Italy from the War Economy to Limited Convertibility, 1953-1958. Quarterly Review,p. 339-483, Dec. 1958.

BANK DEUTSCHER LANDER. Report of the Bank Deutscher Lander for the Years 1948 and 1949. Frankfurt, 1950.

BANK FOR INTERNATIONAL SETTLEMENTS. Annual Report, various issues.

BARRO, R. \& GROSSMAN, H. Money, Employment and Inflation. Cambridge University Press, 1976.

BENNET, J. The German $\mathrm{Cu}_{2}$ ency Reform. Annals of the American Academy of Political and Social Science. v.267, n.1 : p.41-54, 1950.

BOFINGER, P. The German Monetary Unification (Gmu): Converting Marks to D-Marks. Federal Reserve Bank of St. Louis Review, v.72, n.4, p.17-36, July/Aug. 1990.

BROWN, A.J. The Great Inflation 1939-1951. Oxford: Oxford University Press, 1955.

BUCHHEIM, C. Die Wabringsreform 1948 in Westdeutschland. Vierteljahreshefte fur Zeitgeschichte, 36, 1988.

- Zur Kontroverse uber den Stellungswert der Wahrungsreform fur die Wachstumsdynamik in der Bundesrepublik Deutschland. In: HAMPE, P. (ed.). Wahrungsreform und Soziale Marktwirtschaft, Munchen, 1989.

CASELLA, A. \& EICHENGREEN, B. Halting Inflation in Italy and France After World War L. Mimeo, University of California, Berkeley, 1990.

COHEN, J.B. Japan's Economy in War and Reconstruction. Minneapolis: University of Minnesota Press, 1949.

COLM, G.; DODGE, J.M. \& GOLDSMITH, R. A Plan for the L.iquidation of War Finance and for the Financial Rehabilitation of Germany. Zeitschrift for die Gesamte Staatswissenschaft. v.111, p.193-243, 1955.

DENTON, G.; FORSYTH, M. \& MACLENNAN, M. Economic Planning and Policies in Britain, France and Germany. London: George Allen \& Unwin, 1968.

DIETER.LEN, P. \& RIST, C. The Monetary Problem of France New York: King's Crown Press, 1948.

DORNBUSCH, R. \& FISCHER, S. Stopping Hyperinflations Past and Present. Weltwirtschaftliches Archiv. v.122, n. i, p.1-47, 1986.

DORNBUSCH, R.; STURZENEGGER, F. \& WOLF, H. Extreme Inflation: Dynamics an Stabilization. Brookings Papers on Economic Activity. Forthcoming, 1990.

DUPRIEZ, L. Monetary Reconstruction in Belginm. New York: King' Crown Press, 1947.

FOA, B. Monetary Reconstruction in Italy. New York: King's Crown Press, 1949.

GOLDSMITH, R. The Financial Development of Japan, 1868-1977. New Haven: Yale University Press, 1983.

GROTIUS, F. Die Europaischen Geldreformen Nach Dem Zweiten Welturieg. Weltwirtschaftliches Archiv. v.62, n.1, p.106-52, 1949a.

- Die Europaischen Geldreformen Nach Dem Zweiten Weltkries II. Weltwirtschaftliches Archiv. v.\&3, n.2, p.276-325, 1949 b. 
GUGgenHEIM, T. La Reforme Monetaire Aprè Ia Denxiżme Guerre Mondiale $G$ nève: Goorge \& Cie, 1965.

GURLEY, J. Excess Liquidity and European Monetary Reforms. American Economic Review, v.43, n.1, p.76-100, Mar., 1953.

HANSEN, A. \& MUSGRAVE, R. Fiscal Problems of Germany. Bonn: Minister of Finance of the Federal Republic Germany, 1951.

HELLER, W. Tax Policy and Monetary Reform in Occupied Germany. National Tax Journal v.2, n.3, p.215-31, 1949.

HOLTZMAN, F. Soviet Taxation.Cambridge: Harvard University Press, 1962.

HUNOLD, A. Wirtschaft Ohne Wunder. ErlenbschZurich: Eugen Rentsch Verlag, 1953.

INTERNATIONAL MONETARY FUND. The Economy of the USSR. Washington: DC, 1990.

KAPLAN, J. \& SCHLEIMINGER. The European Payments Union Oxford: Oxford University Press, 1989.

KLEIN, J. German Money and Prices, 1932-44. In: FRIEDMAN, M. (ed.) Stndies in the Quantity Theory of Money. Chicago: University of Chicago Press, 1956.

KLEMM, B. \& TRITTEL, G. Vor dem "Wirtschaftswunder": Durchbruch zum Wachstum oder Lahmingskrise?, Vierteljahreshefte fur Zeitgeschichte, 35, 1987.

KLOPSTOCK, F. Monetary Reform in Western Germany, Journal of Political Economy, v.58, n.4, Aug. 1949.

- Monetary Reform in Liberated Europe. American Economic Review, v.36, p.578-95, Sept. 1946.

LIEFTINCK, P. The Postwar Financial Rehabilitation of the Netherlands. The Hague: Martinus Nijhoff, 1973.

LUTZ, F. The German Currency Reform and the Revival of the German Economy. Economica, v.41, n.61, p.122-14, litây 1949.

MEDERSHAUSEN, H. Prices, Money and the Distribution of Goods in Postwar Germany. Amerian Economic Review, v.39, n.5, p.646-72, Sept. 1949.

METZLER, L. Experiences With Monetary and Financial Reform. In: RICHTER, R. (ed.) Currency and Economic Reform: West Germany After World War II: A Symposium. In: Zeituchrift fur die Gesamte Stantswissenschaft, v.135, n.3, p.365-73, Spring 1979 (originaly published in 1949).

MILWARD, A. The Reconstruction of Western Europe 1945-51. Berkeley: University of San Francisco Press.

MTCHELL, B.R. European Historical Statistics. New York: Columbia University, 1978.

MOELLER, H. Die Westdeutsche Nahrungsreform von 1948 In: DEUTSCHEBUNDESBANK. Wachrung and Wirtschaft in Deutschland 1876-1975. Frankfurt: Deutsche Bundesbank, 1976.

(ed.) Zur Vorgeschichte der Deutschen Mark.Basel: Kyklos Verlag, 1961.

- Die Wahrungsreform von 1948 und die Wiederherstellung marktwirtschaftlicher Verhaltnisse. In: HAMPE, P. (ed.). Wahrungsreform und Soziale Marktwirtechar: Minchen, 1989.

MONTIAS, J.M. Inflation and Growth: The Experience of Eastern Europe. In: BAER, W. \& KERSTENETSKY, I, (eds.) Inflation and Growth in Latin America. New Haven: Yale University Press, 1964.

PEDERSON, J. An Evaluation of Postwar Monetary Weltwirtschaftliches Archiv, v.62, p.198-213, 1943.

PESEK, B. Monetary Reform and Monetary Equilibrium. Journal of Political Economy, v.66, n.5, p.375, Oct. 1958 .

REUSS, F. Fiscal Policy For Growth Without Inflation. The German Experiment. Batimore: Johns Hopkins University Press, 1963.

RICHTER R. (ed.) Currency and Economic Reform: West Germany After World War II: A Symposium. In: Zeitschrift fur die Gesamte Stawissenschaft, v.135, n.3, Spring, 1979.

RITSCHL, A. Die Wahrungsreform von 1948 und der Wiederaufstieg der Westdeutschen Industrie. Vierteljahresheftys der Zeitgeschichte, 33, 1985.

SAUERMANN, H. The Consequences of the Currency. Reform in Western Germany, Review of Politics, v.12, p.175-196, 1950. 
. On the Economic and Financial Rehabilitation of Western Germany. In: RICHTER, R. (ed,) Currency and Economic Reform: West Germany After World War II: A Symposium. In: Zeitschrift fux die Gesemte Stantwwissenuchaft, v.135, n.3, Spring. 1979.

SCHILLER, K. Wirtschaftspolitische Konsequenzen der Wahrungsreform. In: HAMPE, P. (ed.) Wahrungsreform und Soziale Marktwirtschaft, Munchen, 1989.

SHLEIMINGER, G. Geldpolitische Ertahrungen der Danischen Anti, Weltwirtuchaftliches Arhiv, v.63, n.2, p.232-73, 1949.

SCHLESINGER, H. Vierzig Jahre Wahrungsreform, In: HAMPE, P. (ed.). Wahrungsreform und Soziale Marktwirtachaft, Munchen, 1989.

SCHMOELDERS, G. Die Zigarettenwahrung. In: Soxialokonomiache Verhaltensforschung, Festachrift G. Schmoelders, Berlin.

SHEPERD, H. The Monetary Experience of Belgium. New York: Arno Press, 1936.

SHERWIN, S. Monetary Policy in Continental Western Europe 1944-52. Madison: University of Wisconsin Press, 1956.

SNIDER, D. French Monetary and Fiscal Policies Since the Liberation. American Economic Review, v.38, n.3, p.309-27, 1948.

STOLPER, W. \& ROSKAMP, K. Planning a Free Economy: Germany 1945-1960. In: UNITED NATIONS. Economic Comission for Europe (1948): A Survey of the Economic Situation and Prospects of Europe. Geneva, 1979.

VEIT, O. Grundriss der Wahrungspolitik, Frankfurt: Fritz Knapp Verlag, 1961. WALLICH, H. The Mainsprings of German Revival. New York: Harper, 1960.

WANDEL, E. Historical Developments Prior to the Currency Reform of 1948. Zeitachrift fur dic Geante Stantswissenschaft, v.135, n.3, p.320-31, Spring, 1979.

WIRTSCHAFTS-JAHRBUCH. Suddentsche Zeitung 1948, 1949, 1950.

WOLF, H. From Plan to Market: Germany 1948 and 1990. Mimeo, Massachusetts Institute of Technology, 1990.

\section{SINOPSE}

\section{CRISES E REFORMAS MONETÁRIAS NA DECADA DE QUAFENTA}

Logo após 1945, a Europa apresentava muitas das características observadas boje no Leste europeu e na Uniắo Soviética: controle de preços, racionamento, mercados paralelos e crise monetária. A política adotada, na maioria dos páses, foi a reforma monetária, comprecidendo a imobilizaç⿸尸o deliberada de ativos líquidos e, em muitos casos, o confisco dos depósitos. Este artigo revisa a experiéncia histórica, com destaque para a reforma da Alemanha de 1948, identifica as políticas formuladas e deduz liçøes para os dias atuais. 